\title{
Analysis and Research of ASTW Method in the Management of College Basic Department
}

\author{
Yanfei Liu, Lei Xie, Jun Liu, and Jingcun Bi \\ Xi'an Research Inst. Of Hi-Tech, Xi’an, Shanxi, China
}

\begin{abstract}
On the basis of management work, main responsibilities and characteristics of college department are analysised and how to improve work efficiency and effectiveness of the director of department is studied. A four step method called ASTW is put forward and discussed in detail. Management practice of department in recent years has shown that it can have good results in teaching and research of department and improving the management level of the director.
\end{abstract}

Keywords - Management of department, innovative thinking, work thinking

\section{高校基层教研室管理工作 ASTW 方法分析与研究}

\author{
刘延飞 谢䂞 刘君 毕经存 \\ 西安高新技术研究所, 西安, 陕西, 中国
}

\begin{abstract}
摘 要 本文从高校教研室管理工作出发, 分析高校教研室工作特点和主要职责, 研究如何提高教研室主任工作效率和效果, 提出 工作思路 ASTW 四步法的管理方法并详细论述。在近几年的教研室教学管理实践表明,使用这种方式对教研室工作开展和提高教研室 主任管理水平都有较好的效果。
\end{abstract}

关键词 教研室管理 创新思维 工作思路

1. 引言

教研室是在高校领导下开展教学与科研工作的最基层 教学单元 ${ }^{[1]}$, 承担着高校教育思想、教学计划的具体落实, 是培养新型高素质人才的基本单元。教研室主任是教研室 的第一责任人, 全面负责本教研室的各项教学工作, 组织 全体教研室人员努力完成各项教学任务, 其作用发挥的好 坏直接影响着人才培养的效果。因此, 探讨教研室主任如 何更好地履行自己的职责, 是高校管理工作中一个非常重 要的课题。根据教研室工作的基本特点和所承担的使命, 一个好的教研室主任应当结合本单位实际, 建立层次清晰、 范围适度、方法恰当的具体工作思路, 掌握好勤问、好学、 慎思、多行四个关键环节。

\section{2. 教研室主任工作职责}

教研室工作涉及面广, 任务琐碎, 总的来说, 主要是 带领教研室全体教师, 按照高等教育的办学规律和本校的 办学方针, 认真完成学校的教学工作 ${ }^{[2,3]}$ 。关心教师, 作好 教师的思想政治工作。具体有以下三方面工作。

\section{1 政治思想工作}

贯彻“德育(学生品行教育、师德教育)放在首位”的指导 思想, 在教学、科研活动中, 发挥德育功能, 结合教学的 相关内容和各个环节, 积极主动地实施德育教育, 将对学 生、对教师的德育工作贯穿于教学、科研工作的全过程。

\section{2 行政管理工作}

首先是负责制定和组织实施/执行教研室的发展规划、 年度工作计划、教研室的有关规章制度, 总结、汇报教研 室的工作。其次, 负责教研室教师的工作安排和工作量的 检查、核定工作, 做好教师综合测评工作。最后, 配合其 他职能部门组织教学工作检查和教学质量评估。

\section{3 业务工作}

认真组织教学, 积极开展教学研究和教学改革, 把提 高教学质量作为经常性的中心工作来抓。根据教学计划和 教学工作基本要求以及其他各项教学规章制度, 全面完成 学校下达的各项教学任务。 
(1)组织制定、修订和实施专业方案、教学执行计划、 教学大纲以及决定教材的选用, 组织教材与教学参考资料 的编写。如果能规定专业培养方案的字数, 估计我们的质 量好很多。

(2) 严密组织教学过程, 组织教学研究、教学法活动和 教学检查。严密组织教学过程, 就是从教师的备课、讲课、 辅导答疑、批改作业、实验、实习、社会实践、课程设计、 毕业设计 (论文)、出题阅卷等教学环节入手, 检查各项教 学规章制度的落实、执行情况, 发现问题, 采取措施解决。

(3)抓好学科 (专业) 和课程建设。主要有科学规划学 校的学科和专业结构体系; 拓宽本科专业口径、扩大专业 基础, 主干学科或主要学科基础相同的专业应尽可能合并, 增强学生适应性; 稳定和提高基础学科水平, 形成基础与 应用学科的互补; 重视发展应用学科和专业, 培养复合型 人才; 更新传统学科及专业, 适度发展新兴学科、交叉边 缘学科及专业; 发挥本校优势, 办出特色; 要注意根据学 科与社会发展, 适时进行专业设置、专业方向、培养目标 和教学内容的调整。

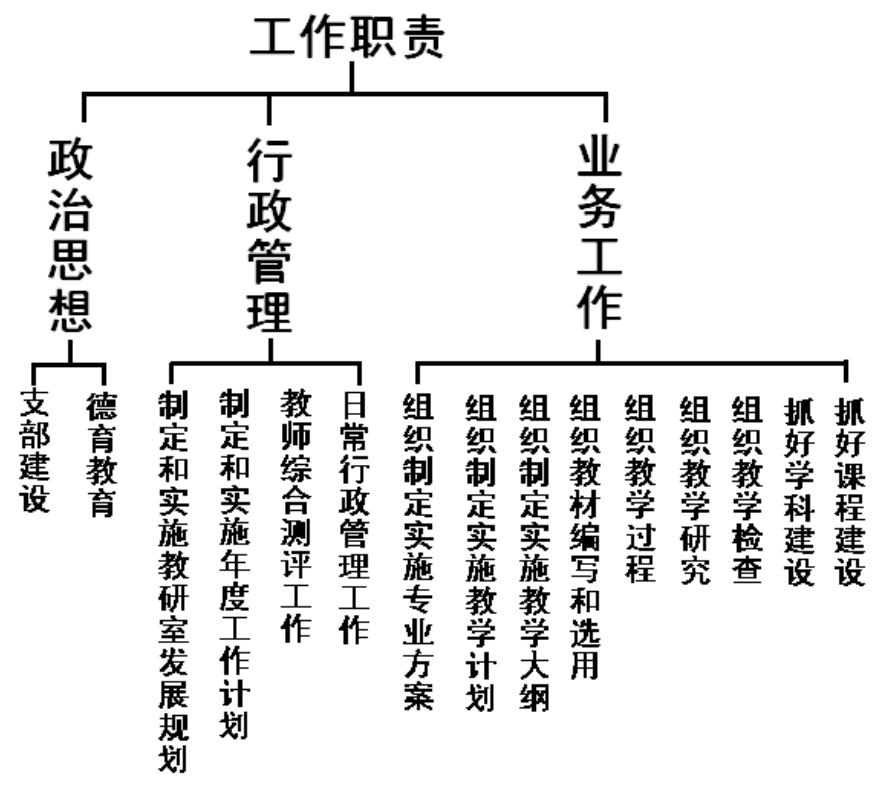

图 1 教研室工作结构图

\section{ASTW 工作思路模型}

教研室的工作特点 ${ }^{[4,5]}$ 是面宽、具体、繁杂, 在纷乱复 杂的工作中要想有一个清晰地工作思路和高效的工作方 法, 必须要有一套完整的工作流程, 既可以让日常工作有 章可循, 也可以让具体工作条理清晰, 事半功倍。我们提 出勤问 (ASK)、好学 (Study)、慎思 (Think)、多行 (Work) 四步工作法, 具体方法和注意问题分析如下。

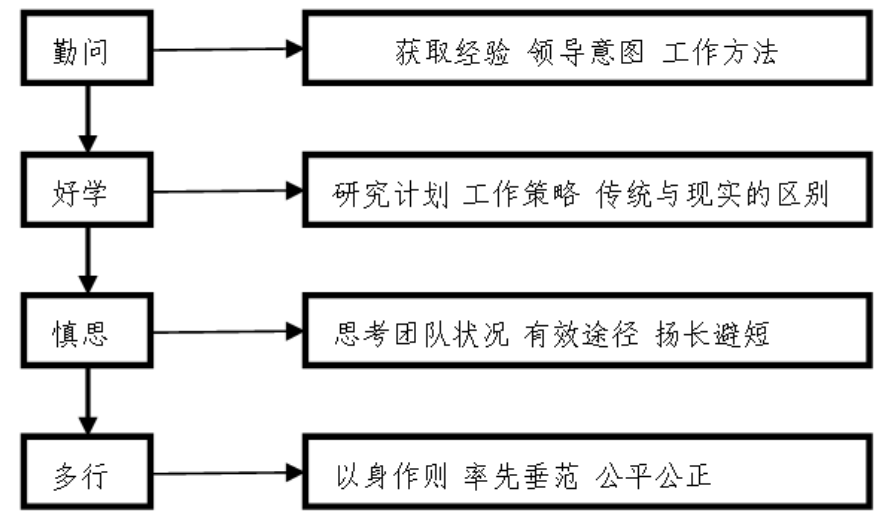

图 2 ASTW 工作法结构框图

一、“勤问”。问领导、问前辈、问部属, 做好工作筹 划, 把握好工作重点, 引领教研室沿着正确的方向发展。 问领导, 可以正确领悟领导和机关工作意图, 知道干什么, 干成什么样; 问前辈, 虚心向老教授、老领导学习成功的 经验与做法, 了解教研室工作的基本规律, 掌握该怎么干; 问部属, 广开言路, 发挥集体的智慧和力量干好每一件事。 通过这三问, 可以帮助我们明确方向, 理清思路, 掌握方 法。

二、“好学”。作为教研室主任, 应该全面提高自身素 质和领导能力, 注重学习和培养以下三种能力: 一是谋划 能力。所谓谋, 就是谋略; 所谓划, 就是规划、计划。每 一任教研室领导不过几年的任期, 做的如何, 不仅影响到 教研室这几年的发展, 也影响到今后。因此, 在“问”的基 础上, 经过缜密的思考和论证, 筹划好单位近期和中长期 的发展规划, 是教研室主任的首要任务。例如我校专业基 础实验中心工程坊已经在学校、二炮乃至全军具有一定的 影响, 在未来的工作中, 强化质量意识、服务意识, 注重 教学、管理能力的提升, 将工程坊打造出品牌效应, 争创 全军首批示范性实验教学中心是我们努力的方向。二是共 事的能力。所谓共事能力就是与支部一班人搭班子的能力。 力争做到“多尽职、不争权; 多负责, 不推委; 多交心, 不 积怨; 多体谅, 不攀比”; 在工作配合中相互信任、相互学 习、相互通气、相互支持。三是抓重点的能力。身为教学 单位, 教学是重点工作, 但就全面工作而言, 一个时期、 一个阶段都会有自己的重点, 协调好总的重点与阶段性重 点的关系, 学会统筹安排, 处理好主与次的辨证关系。把 力量投入到重点上; 狠抓落实, 楔而不舍, 持之以恒, 同 时兼顾非重点工作。

三、“慎思”。教研室主任既是本教研室的行政领导又 是所在党支部的组织领导, 经常性的政治思想教育和经常 性的管理工作是最基本的任务, 是高效完成各项任务的前 
提条件, 因此, 必须时时在思想上环磨如何开展好这两项 经常性的工作, 做到变不利为有利、变被动为主动, 将问 题发现在隐藏阶段, 消除在萌芽状态, 具体实施过程中要 做到用心、用情、持之以恒, 贵在经常, 也难在经常。

虽然每个教研室人数不多, 但管理任务非常繁重, 并 且人的思想不断变化, 知识分子的思想问题不可能采取暴 风骤雨式的解决方法, 而是需要春风化雨, 因此, 在日常 工作中做到眼勤多看、耳勤多听、脑勤多想, 将思想工作 融合在日常的管理工作中, 化在一件又一件的具体的事情 中。

四、“多行”。教研室主任的一言一行直接影响着整个 教研室的工作氛围和价值趋向。作为教研室领导, 应该做 到身先士卒, 率先垂范, 在具体工作中争做“四个模范”:

1、热爱学习的模范。不学习就要落后, 不学习就要淘 汰。不仅要注重业务上的学习和完善, 更要注重政治思想 上的理论武装, 在政治上、思想上与党中央、中央军委和 各级党委保持高度一致。

2、要当教学科研的模范。俗话说打铁还需自身硬, 自 己是权威就有说服力、感召力、影响力。作为教学单位的 领导, 首先应该是本专业的行家里手, 成为本教研室的教 学科研的组织者、带头人。例如我校专业基础实验中心科 研项目少、科研能力弱的实际, 教研室主任应该鼓励大家 积极开展课题申报和横向课题的参与, 主动牵头与 985 、 211 院校教研室建立科研联合团队, 引领大家参与到科研 活动中去, 在科研中锻炼能力, 促进教学质量的进一步提 升。

3、师德的模范。教研室主任本身就是教师, 应该在师 德方面为人表率; 做人堂堂正正, 任教兢兢业业, 不图虚 名, 不犯自由主义。工作中严格要求, 生活上注意小节, 用人格魅力带动部属。专业基础实验中心承担的主要教学 任务是实验和工程实践课, 就必须按照有关实验课程授课 规范严格要求自己, 以高质量的授课为全中心的同志做好 示范作用。

4、遵章守纪的模范。凡是要求部属做到的, 自己首先 做到, 要求别人不做的, 自己带头不做。一是在政治上, 不该说的不说, 不传、不信小道消息, 要求传达的精神一 定传达到每一位同志。二是在经济上。教研室钱不多, 权 不大, 但如果处理不好, 同样会出现廉洁问题, 严格帐目 公开制度, 管用分离制度。三是在立功受奖问题上。严格 评选程序, 做到公平、公正、公开。

\section{4. 结束语}

比尔. 盖茨曾说: 一个人科研取得小成功, 团队才能取 得大成功。作为一个优秀的教研室主任, 时刻应该牢记尊
重他人, 就是尊重自己; 谦虚使人进步, 骄傲使人落后; 大家的支持就是你的成功; 不要服输, 要勇争先, 是事业 成功之本; 不要畏难, 要乐观, 是身心健康的基础。一花 独放不是春, 万紫千红春满园。教研室主任起到承前启后、 承上启下的作用, 要把前辈的优良传统、好的品德和成功 经验传下去, 带领好广大教员进入新层次, 获得更大的成 功。

\section{参考文献(References)}

[1] Binying Song. Five breakthroughs to improve the talent-fostering quality for colleges and universities. Forum on Contemporary Education, 2011, 07.

[2] ZHENG Rui. On the teaching quality evaluation system and method for teachers in colleges and universities. Journal of Shenyang Institute of Aeronautcal Engineering, 2005, 06.

[3] ZOU Jun-jie. Discussion on the management of university teachers of Contemporary College Students. Journal of Nantong Vocational \& Technical Shipping College, 2005, 03.

[4] Yuan Li, Sun Shanshan. Research and practice of teaching quality evaluationsystem of University Teachers. Journal of Suihua University, 2006, 04.

[5] Zhu Hongqiong. On the evaluation of teaching quality of teachers in Colleges and Universities. Taxation and Economy,, 2008, 01 .

[6] Huisheng Li. Management innovation and education innovation of high school. Chinese Public Administration, 2007, 05:81-83.

[7] Yue Zhuo, Xiaohui Xu. Countermeasures to cultivate innovative talents in Colleges and Universities. Journal of Changchun University of Science and Technology, 2005, 04.

[8] LIU Zhi-yun. On the cultivation of innovative talents in colleges and universities. Journal of China University of Geosciences (Social Sciences Edition), 2007, 02.

[9] Datong Feng, Wenmei Yu. Way of cultivating innovative talents in universities. Journal of Changchun University of Technology (Higher Education Study Edition), 2005, 02.

[10] WU Hui-fang, GUO Qing-lin. On the cultivation of innovative talents in colleges and universities. Journal of North China Electric Power University(Social Sciences), 2006, 02

[11] WANG Li-ping, CUI Yan-mei. Opinion about the quality training of Engineering College Students. Journal of Zhengzhou Institute of Aeronautical Industry Management, 2002, 03.

[12] Yubo Su, Li Liang, Zhengwei Zhu. Cultivating students' consciousness of engineering and engineering and engineering quality. JOURNAL OF XI'AN JIAOTONG UNIVERSITY (SOCIAL SCIENCES EDITION), 1999, 02.

[13] Zhu Bin, CAO Manxiang etal. Improve the Engineering Qualification of Engineering Students with Opportunity of Discipline Competition. Computer Knowledge and Technology, 2011, 17. 